\title{
CLINICAL AND MORPHOLOGICAL CORRELATION DEPENDENCIES AND THEIR SIGNIFICANCE IN PATIENTS WITH COMPLICATIONS OF LABORED ERUPTION OF THE LOWER THIRD MOLARS
}

DOI: 10.36740/WLek202103111

\author{
Vladislav A. Malanchuk', Oksana S. Volovar', Mykola V. Oblap', Igor S. Brodetskyi', Tatyana V. Dobryi-Vechir', \\ Valerii V. Hryhorovskyi' ${ }^{2}$ Liudmyla 0. Brodetska', Olena 0. Dyadyk³ ${ }^{3}$, Mykhailo S. Myroshnychenko ${ }^{4}$ \\ 'BOHOMOLETS NATIONAL MEDICAL UNIVERSITY, KYIV, UKRAINE \\ ¿STATE INSTITUTION «INSTITUTE OF TRAUMATOLOGY AND ORTHOPEDICS OF THE NATIONAL ACADEMY OF MEDICAL SCIENCES OF UKRAINE», KYIV, UKRAINE \\ ${ }^{3}$ SHUPYK NATIONAL HEALTHCARE UNIVERSITY OF UKRAINE, KYIV, UKRAINE \\ ${ }^{4}$ KHARKIV NATIONAL MEDICAL UNIVERSITY, KHARKIV, UKRAINE
}

\begin{abstract}
The aim is to determine the clinical and morphological dependencies, which are important for diagnostics, treatment and prediction of outcomes of pathological processes in the region of the LTM with complicated eruption, as based on the study of histopathological changes of paradental tissue (mucous membrane, walls of retromolar pocket, alveolar bone tissue). Materials and methods: The materials of the study were 34 biopsy specimens of pathologically altered soft tissue and parodontium obtained as a result of pericoronectomy, extraction of the LTM and other surgical interferences performed based on the relevant indications in 28 patients in the region of the LTM with complicated eruption. Morphological and statistical research methods were used.

Results: The local pathological processes, which chronologically precede the destructive changes in the hard tissue of a tooth (caries), are developed in patients of both genders with complicated LTM eruption in soft tissue of parodontium and the adjacent bone tissue of the alveolar wall in the majority of cases. As per biopsy examinations, the frequency of the main pathological processes in paradental tissue in case of complicated LTM eruption varies from 25 to $60 \%$ of the number of biopsy specimens and occurs in various combinations in patients with different values of clinical parameters. The correlation relationships between the patients' clinical data and the morphological parameters of damage to paradental tissue are weak, multidirectional and uncertain in the majority of combinations (considering the available number of biopsy specimens studied). The close certain positive dependence between the damage of the squamous epithelium and the inflammation activity in the lamina propria mucosae, covering the tooth: in the vast majority of cases, the presence of damaged epithelium (within the biopsy specimen) is associated with the inflammation of high activity, was established as based on correlation relationships between the morphological parameters of damage to paradental tissue.
\end{abstract}

Conclusions: The found pathological changes and the correlations justify surgical tactics on paradental soft and osseous tissues that are directed on the LTM sparing.

KEY WORDS: pathomorphological features, clinical and morphological correlation dependencies, labored eruption, lower third molars

Wiad Lek. 2021;74(3 p.l):441-449

\section{INTRODUCTION}

The labored eruption of the LTM is one of the disturbances of the dentomaxillary system development, which is relatively frequently complicated by different pathological processes in the soft tissue and the parodontium of the third molar triggering the necessity of surgical interference [1-3].

There is no consensus in the related reference sources on the issue of the indications for the extraction of the intact LTM in case of complications of their eruption. A range of authors, who identified more frequent development of pathological changes in paradental tissue in the region of the LTM, support an idea of the relevance of "preventive» extraction of the intact LTM [4-9]. Other authors highlight the relatively low frequency of complications in the «restricted» LTM, which evidences in favor of an expectant treatment [10-13]. There are few research studies published on histological peculiarities of the separate pericoronal complications in the region of the
LTM, and the correlation dependencies between the clinical data and histological peculiarities of the damage $[14,15]$.

\section{THE AIM}

The aim is to determine the clinical and morphological dependencies, which are important for diagnostics, treatment and prediction of outcomes of pathological processes in the region of the LTM with complicated eruption, as based on the study of histopathological changes of paradental tissue (mucous membrane, walls of retromolar pocket, alveolar bone tissue).

\section{MATERIALS AND METHODS}

The materials of the study were 34 biopsy specimens of pathologically altered soft tissue and parodontium obtained as a result of pericoronectomy, extraction of the 
Table 1. The frequency of biopsy specimens distribution of various qualitative/semi-quantitative gradation of clinical parameters in patients with complicated eruption of the LTM

\begin{tabular}{|c|c|c|c|}
\hline $\begin{array}{l}\text { Major clinical signs of the } \\
\text { patients who underwent } \\
\text { biopsy of paradental tissue }\end{array}$ & $\begin{array}{l}\text { Description of the clinical parameters } \\
\text { gradation or alternative conditions }\end{array}$ & $\begin{array}{l}\text { Number of biopsy } \\
\text { specimens assigned } \\
\text { to each gradation or } \\
\text { alternative from the total } \\
\text { number of informative } \\
\text { biopsy specimens }\end{array}$ & $\begin{array}{c}\text { Frequency of incidence } \\
\text { of the specific gradation } \\
\text { of clinical parameters, } \\
\% \text { of the number of } \\
\text { informative biopsy } \\
\text { specimens }\end{array}$ \\
\hline \multirow{3}{*}{$\begin{array}{l}\text { Patient's age at the moment } \\
\text { of biopsy performance }\end{array}$} & Up to and including 25 years of age & 19 & 55.9 \\
\hline & Over 25 years of age & 15 & 44.1 \\
\hline & Total number of biopsy cases considered & 34 & 100.0 \\
\hline \multirow{3}{*}{ LTM condition } & Intact & 31 & 91.2 \\
\hline & Moderate or deep caries & 3 & 8.8 \\
\hline & Total number of biopsy cases considered & 34 & 100.0 \\
\hline \multirow{3}{*}{$\begin{array}{l}\text { Degree of the top of LTM } \\
\text { crown overlapping by the } \\
\text { mucous membrane }\end{array}$} & Less than half of the surface & 14 & 41.2 \\
\hline & The half of the surface and more & 20 & 58.8 \\
\hline & Total number of biopsy cases considered & 34 & 100.0 \\
\hline \multirow{4}{*}{$\begin{array}{l}\text { Extent of antagonist tooth } \\
\text { eruption }\end{array}$} & Absence of antagonist tooth & 6 & 17.6 \\
\hline & Retention and semi-retention & 11 & 32.4 \\
\hline & Complete tooth eruption & 17 & 50.0 \\
\hline & Total number of biopsy cases considered & 34 & 100.0 \\
\hline \multirow{3}{*}{ LTM position in a jaw } & Vertical & 24 & 70.6 \\
\hline & $\begin{array}{l}\text { All others (medial oblique, dorsal oblique, } \\
\text { buccal, glossal, horizontal) }\end{array}$ & 10 & 29.4 \\
\hline & Total number of biopsy cases considered & 34 & 100.0 \\
\hline \multirow{3}{*}{$\begin{array}{c}\text { The age of the onset of signs } \\
\text { of the LTM complicated } \\
\text { eruption }\end{array}$} & Less than 12 months & 18 & 52.9 \\
\hline & 12 months and over & 16 & 47.1 \\
\hline & Total number of biopsy cases considered & 34 & 100.0 \\
\hline \multirow{3}{*}{$\begin{array}{l}\text { Pericoronitis activity as of } \\
\text { the moment of biopsy (as } \\
\text { per clinical findings) }\end{array}$} & Chronic in the stage of remission & 17 & 50.0 \\
\hline & Acute and chronic in the stage of exacerbation & 17 & 50.0 \\
\hline & Total number of biopsy cases considered & 34 & 100.0 \\
\hline
\end{tabular}

LTM and other surgical interferences performed based on the relevant indications in 28 patients in the region of the LTM with complicated eruption. 8 biopsy specimens were obtained of patients 16-20 years old, 10 ones - of patients 21-25 years old, 11 ones - of patients 26-30 years old, 5 ones - of patients 31 years of age and older. The objects of the limited resection were as follows: soft tissue fold of the mucous membrane of the oral cavity (flap) covering the LTM with complicated eruption - 32 objects, the retromolar pocket wall -8 objects, the periosteum and small (not more than $1 \times 2 \mathrm{~mm}$ ) bone fragments of the alveolar process margin -13 objects.

The resected tissue was fixed in $10 \%$ formalin solution, processed into histological blocks, decalcinated in a 5\% nitric acid solution if needed, embedded into celloidin after the relevant histological preparation. The sections, $10 \mu \mathrm{m}$ in thickness, were obtained and stained with hematoxylin and eosin, hematoxylin-picrofuchsin by van Gieson technique.

As based on the results of the clinical, X-ray and histological examinations, the qualitative/semi-quantitative gradations of clin- ical and morphological parameters were determined (table 1,2). The correlation analysis has been performed after gradation quantification of all biopsy specimens and frequency analysis of the received material, namely, the statistical contingency between the clinical and morphological parameters (clinical issues - morphology) and statistical contingency of separate morphological parameters between themselves (morphology - morphology), with calculation of tetrachoric correlation coefficient, its value and degree of certainty were determined (table 3 ).

\section{RESULTS}

The clinical characteristics, their gradation and frequency distribution of cases are provided in table 1 .

The pathological changes of tissue, surrounding the LTM with complicated eruption, of various extensiveness and severity were found in all biopsy specimens (table 2). The examined resectates of the mucosa, covering the LTM (fig. 1), included the altered epithelium, the lamina propria mucosae, the muscle tissue, the end sections and ducts of minor 
Table 2. The frequency of incidence of various qualitative/semi-quantitative gradation of morphological parameters in biopsy specimens of the patients with complicated eruption of the LTM

\begin{tabular}{|c|c|c|c|}
\hline $\begin{array}{l}\text { Major morphological } \\
\text { parameters of the } \\
\text { biopsy tissue condition }\end{array}$ & $\begin{array}{l}\text { Description of the pathological } \\
\text { changes gradation or alternative } \\
\text { conditions }\end{array}$ & $\begin{array}{l}\text { Number of biopsy specimens } \\
\text { assigned to each gradation } \\
\text { or alternative from the total } \\
\text { number of informative } \\
\text { biopsy specimens }\end{array}$ & $\begin{array}{c}\text { Frequency of incidence of } \\
\text { the specific gradation or } \\
\text { pathological changes, } \% \text { of } \\
\text { the number of informative } \\
\text { biopsy specimens }\end{array}$ \\
\hline \multirow{3}{*}{$\begin{array}{l}\text { Damage to epithelium } \\
\text { of the mucosa and/or } \\
\text { retromolar pocket wall * }\end{array}$} & $\begin{array}{l}\text { The epithelium is preserved within the } \\
\text { extent of the biopsy specimen }\end{array}$ & 15 & 48.4 \\
\hline & $\begin{array}{l}\text { The necrosis and/or ulcers are found } \\
\text { in the epithelium within the extent of } \\
\text { the biopsy specimen }\end{array}$ & 16 & 51.6 \\
\hline & $\begin{array}{l}\text { Total number of biopsy specimens } \\
\text { considered }\end{array}$ & 31 & 100.0 \\
\hline \multirow{3}{*}{$\begin{array}{l}\text { Condition of the mucosal } \\
\text { epithelium and/or } \\
\text { retromolar pocket * }\end{array}$} & $\begin{array}{c}\text { Multi-layered non-keratinized } \\
\text { squamous epithelium }\end{array}$ & 19 & 61.3 \\
\hline & $\begin{array}{c}\text { Multi-layered squamous, with areas } \\
\text { of keratinization manifested by } \\
\text { orthokeratosis or parakeratosis }\end{array}$ & 12 & 38.7 \\
\hline & $\begin{array}{c}\text { Total number of biopsy specimens } \\
\text { considered }\end{array}$ & 31 & 100.0 \\
\hline \multirow{3}{*}{$\begin{array}{l}\text { Hyperplasia of basal } \\
\text { epithelial layers * }\end{array}$} & Absent & 8 & 26.7 \\
\hline & Present & 22 & 73.3 \\
\hline & $\begin{array}{l}\text { Total number of biopsy specimens } \\
\text { considered }\end{array}$ & 30 & 100.0 \\
\hline \multirow{3}{*}{$\begin{array}{l}\text { Discirculatory changes } \\
\text { in the lamina propria } \\
\text { mucosae and submucosa } \\
\text { (microhemorrhage, } \\
\text { fibronecrosis) }{ }^{*}\end{array}$} & Absent & 16 & 51.6 \\
\hline & Present & 15 & 48.4 \\
\hline & $\begin{array}{l}\text { Total number of biopsy specimens } \\
\text { considered }\end{array}$ & 31 & 100.0 \\
\hline \multirow{3}{*}{$\begin{array}{c}\text { Activity of inflammation } \\
\text { in the lamina propria } \\
\text { mucosae } \\
\text { and submucosa * }\end{array}$} & $\begin{array}{c}\text { Completely absent inflammation } \\
\text { or proliferative inflammation of low } \\
\text { activity }\end{array}$ & 15 & 48.4 \\
\hline & $\begin{array}{c}\text { Proliferative infiltrative inflammation } \\
\text { of high activity, including exudative, } \\
\text { focal purulent or diffuse }\end{array}$ & 16 & 51.6 \\
\hline & $\begin{array}{l}\text { Total number of biopsy specimens } \\
\text { considered }\end{array}$ & 31 & 100.0 \\
\hline \multirow{5}{*}{$\begin{array}{l}\text { Pathological changes of } \\
\text { biopsy specimen bone } \\
\text { tissue }\end{array}$} & $\begin{array}{l}\text { Osteonecrosis (small focal interstitial, } \\
\text { extended) }\end{array}$ & 8 & 61.6 \\
\hline & Periostitis with periosteal regeneration & 3 & 23.1 \\
\hline & Bone tissue remodeling & 2 & 15.4 \\
\hline & Osteomyelitis, various forms & 2 & 15.4 \\
\hline & $\begin{array}{l}\text { Total number of biopsy specimens } \\
\text { with osseous elements considered }\end{array}$ & 13 & $-{ }^{* *}$ \\
\hline
\end{tabular}

Notes: ${ }^{*}$ - all informative biopsy specimens on alternative basis were considered; ${ }^{* *}$ - the pathological changes of bone tissue were considered as supplementary, not alternative.

salivary glands. The deepithelialized regions of the mucosa, represented by ulcers, were found in squamous epithelium in many cases (fig. 2). The stringy anastomosing growths of the epithelium, penetrating the lamina propria mucosae, was found near those regions in the submucosa (fig. 3).

There was marked fibrosis of the lamina propria mucosae in almost all cases; the small foci of old hemorrhagic infil- tration, microhematomas (fig. 2, 4), assembly of siderocytes and extracellular brown pigment were found in the fibrous tissue at various depth (1-3 mm from the epithelial surface), which can be collectively regarded as outcome of multiple traumas. In some cases, the areas typical for limited purulent inflammation (fig. 5) were observed in the lamina propria mucosae, it has been occasionally accompanied by the local 
Table 3. The results of correlation analysis of the relationships between the clinical and morphological parameters of tissue damage in the area of the lower third molar with signs of complicated eruption (gradation of parameters - see Tables 1,2)

\begin{tabular}{|c|c|c|c|c|c|}
\hline \multirow{2}{*}{$\begin{array}{c}\text { First } \\
\text { parameter* }\end{array}$} & \multirow[t]{2}{*}{ Second parameter* } & \multirow{2}{*}{$\begin{array}{c}n, \\
\text { number of } \\
\text { considered } \\
\text { biopsy } \\
\text { cases }\end{array}$} & \multicolumn{3}{|c|}{$\begin{array}{l}\text { Pearson's tetrachoric correlation } \\
\text { coefficient (coefficient of } \\
\text { association) and its confidence } \\
\text { interval }\end{array}$} \\
\hline & & & $\mathbf{r}_{\mathrm{a}}$ & $\mathbf{t}_{\phi}$ & $\begin{array}{l}\text { Confidence } \\
\text { estimation } \\
r_{a} \text { at } k=n-1\end{array}$ \\
\hline \multicolumn{6}{|c|}{ Clinical issues - morphology } \\
\hline Patient's age & Damage of epithelium & 31 & +0.163 & 0.92 & UC \\
\hline Patient's age & Condition of epithelium & 31 & +0.026 & 0.14 & UC \\
\hline Degree of the LTM crown overlapping by the mucosa & Damage of epithelium & 31 & +0.159 & 0.90 & UC \\
\hline Degree of the LTM crown overlapping by the mucosa & Condition of epithelium & 31 & +0.189 & 1.07 & UC \\
\hline Degree of the LTM crown overlapping by the mucosa & Hyperplasia of epithelium & 31 & -0.009 & 0.05 & UC \\
\hline Degree of the LTM crown overlapping by the mucosa & Dyscirculatory changes in the mucosa & 31 & -0.163 & 0.92 & UC \\
\hline Degree of the LTM crown overlapping by the mucosa & $\begin{array}{l}\text { Activity of inflammation in the mucosa } \\
\text { and submucosa }\end{array}$ & 31 & +0.029 & 0.16 & UC \\
\hline Extent of antagonist tooth eruption & Damage of epithelium & $26^{* *}$ & -0.025 & 0.13 & UC \\
\hline Extent of antagonist tooth eruption & Condition of epithelium & $26^{* *}$ & -0.090 & 0.46 & UC \\
\hline Extent of antagonist tooth eruption & Hyperplasia of epithelium & $26^{* *}$ & -0.135 & 0.69 & UC \\
\hline Extent of antagonist tooth eruption & Dyscirculatory changes in the mucosa & $26^{* *}$ & +0.061 & 0.31 & UC \\
\hline Extent of antagonist tooth eruption & $\begin{array}{l}\text { Activity of inflammation in the mucosa } \\
\text { and submucosa }\end{array}$ & $26^{* *}$ & -0.028 & 0.15 & UC \\
\hline LTM position & Damage of epithelium & 31 & -0.335 & 1.98 & $<0.05$ \\
\hline LTM position & Condition of epithelium & 31 & -0.075 & 0.42 & UC \\
\hline LTM position & Hyperplasia of epithelium & 31 & +0.061 & 0.34 & UC \\
\hline LTM position & Dyscirculatory changes in the mucosa & 31 & +0.051 & 0.28 & UC \\
\hline LTM position & $\begin{array}{l}\text { Activity of inflammation in the mucosa } \\
\text { and submucosa }\end{array}$ & 31 & -0.051 & 0.28 & UC \\
\hline The duration of the onset of signs of complicated eruption & Damage of epithelium & 31 & +0.100 & 0.56 & UC \\
\hline The duration of the onset of signs of complicated eruption & Condition of epithelium & 31 & -0.056 & 0.31 & UC \\
\hline The duration of the onset of signs of complicated eruption & Hyperplasia of epithelium & 31 & +0.009 & 0.05 & UC \\
\hline The duration of the onset of signs of complicated eruption & Dyscirculatory changes in the mucosa & 31 & -0.033 & 0.19 & UC \\
\hline The duration of the onset of signs of complicated eruption & $\begin{array}{l}\text { Activity of inflammation in the mucosa } \\
\text { and submucosa }\end{array}$ & 31 & +0.033 & 0.19 & UC \\
\hline Pericoronitis activity as per clinical findings & Damage of epithelium & 31 & +0.096 & 0.54 & UC \\
\hline Pericoronitis activity as per clinical findings & Hyperplasia of epithelium & 31 & +0.092 & 0.51 & UC \\
\hline Pericoronitis activity as per clinical findings & Dyscirculatory changes in the mucosa & 31 & +0.033 & 0.19 & UC \\
\hline Pericoronitis activity as per clinical findings & $\begin{array}{l}\text { Activity of inflammation in the mucosa } \\
\text { and submucosa }\end{array}$ & 31 & +0.225 & 1.29 & UC \\
\hline \multicolumn{6}{|c|}{ Morphology-morphology } \\
\hline Damage of epithelium & Condition of epithelium & 31 & +0.239 & 1.37 & UC \\
\hline Damage of epithelium & Hyperplasia of epithelium & 31 & -0.050 & 0.28 & UC \\
\hline Damage of epithelium & Dyscirculatory changes in the mucosa & 29 & +0.105 & 0.57 & UC \\
\hline Damage of epithelium & $\begin{array}{l}\text { Activity of inflammation in the mucosa } \\
\text { and submucosa }\end{array}$ & 30 & +0.732 & 5.89 & $<0.001$ \\
\hline Hyperplasia of epithelium & Dyscirculatory changes in the mucosa & 30 & -0.040 & 0.22 & UC \\
\hline Hyperplasia of epithelium & $\begin{array}{l}\text { Activity of inflammation in the mucosa } \\
\text { and submucosa }\end{array}$ & 30 & +0.191 & 1.07 & UC \\
\hline Dyscirculatory changes in the mucosa & $\begin{array}{l}\text { Activity of inflammation in the mucosa } \\
\text { and submucosa }\end{array}$ & 31 & -0.096 & 0.54 & UC \\
\hline
\end{tabular}

Notes: ${ }^{*}$ - full names and gradation of parameters - see Tables 1,$2 ;{ }^{* *}$ - cases with absent antagonist tooth were not taken into account during analysis; $r_{a}$ - value of tetrachoric correlation coefficient; $t_{\phi}$ - measured value of the Student's criterion when evaluating the certainty of the relationship parameter $r_{a^{\prime}} ; p$-error probability when determining the relationship parameter; $U C$ - the differences are uncertain considering the available number of follow-ups. 


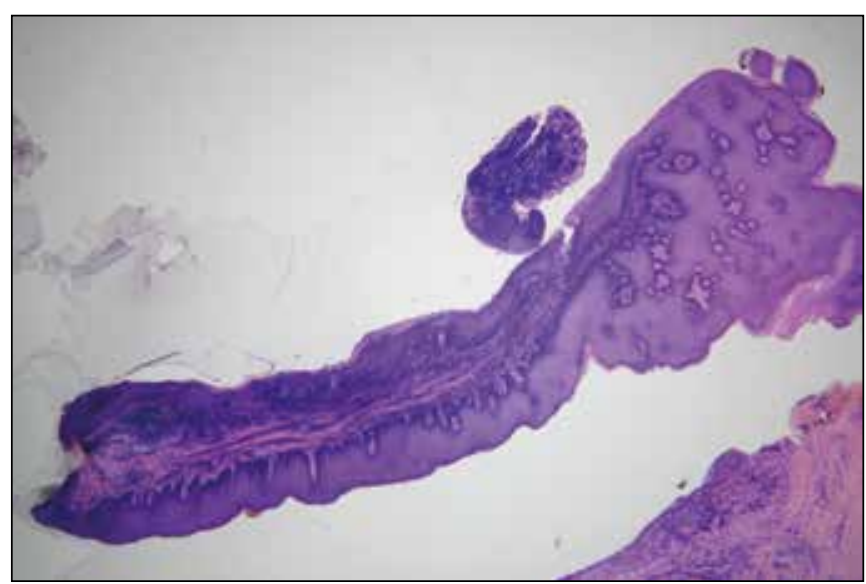

Fig. 1. The mucous membrane of the oral cavity («flap») covering the surface of the LTM with complicated eruption. Photo of a histological specimen of a 24 year old patient. Hematoxylin-eosin staining, $\times 15$.

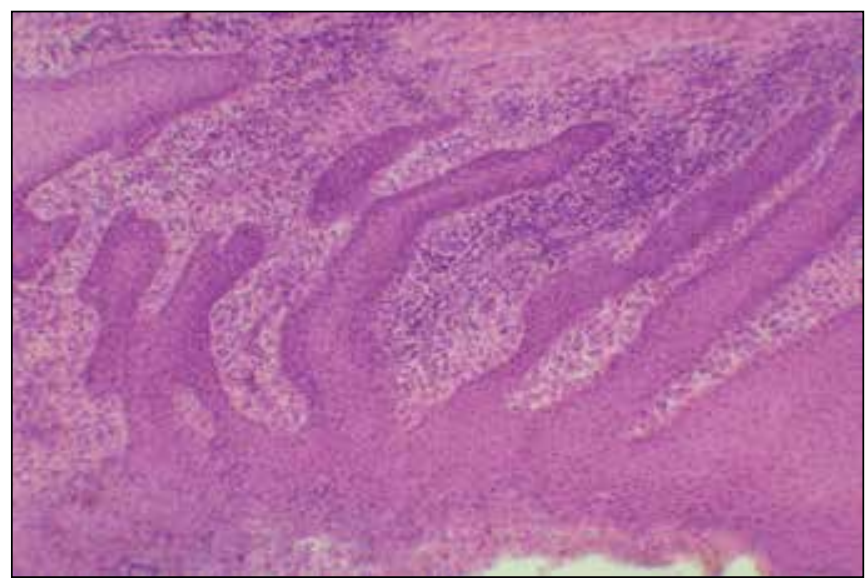

Fig. 3. Marked hyperplasia of multi-layered squamous epithelium in the mucosa, covering the LTM. Photo of a histological specimen of a 36 year old patient. Hematoxylin-eosin staining, $\times 50$.

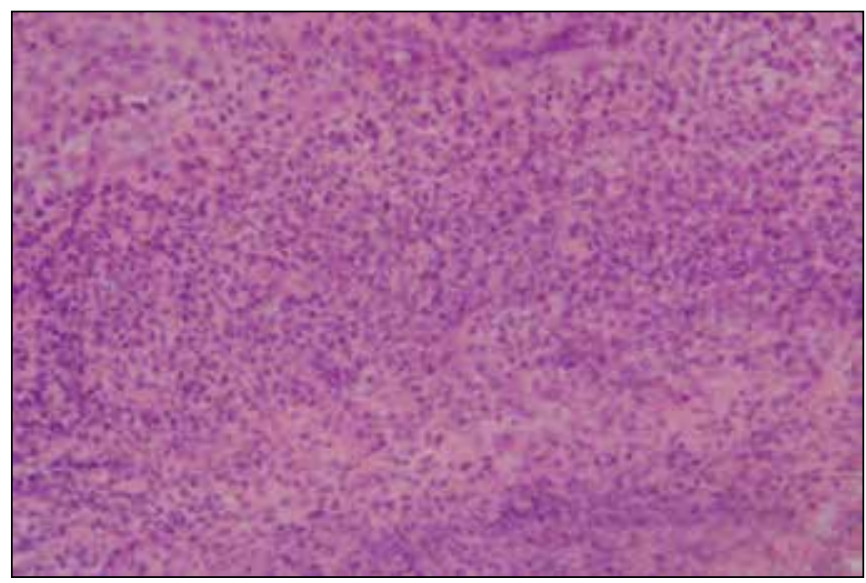

Fig. 5. Diffuse purulent inflammation of the lamina propria mucosae, covering the LTM. Photo of a histological specimen of a 36 year old patient. Hematoxylin-eosin staining, $\times 100$.

tissue destruction which presented the histological pattern of microabscesses. In many cases, the nonspecific inflammatory process did not include marked exudative component and corresponded to proliferative infiltrative inflammation of

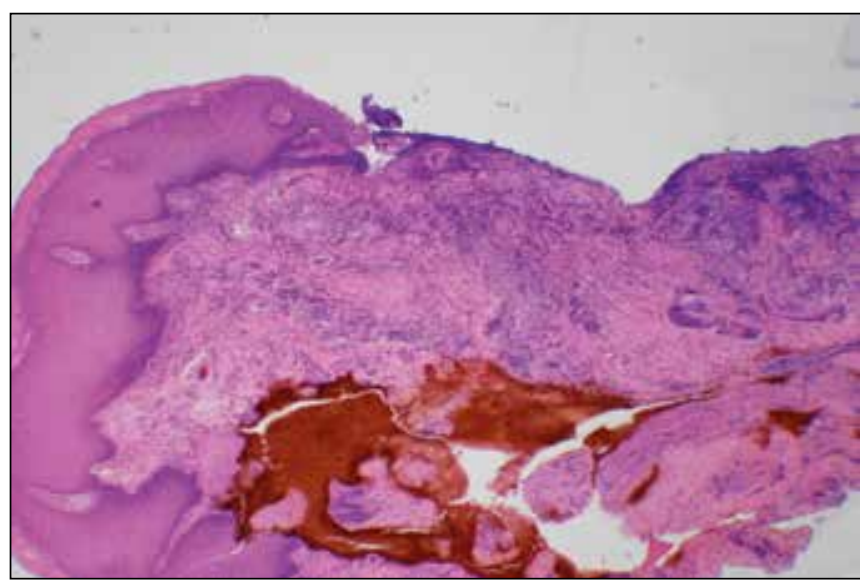

Fig. 2. The area of ulceration in the mucosa, covering the LTM. Photo of a histological specimen of a 27 year old patient. Hematoxylin-eosin staining, $\times 30$.

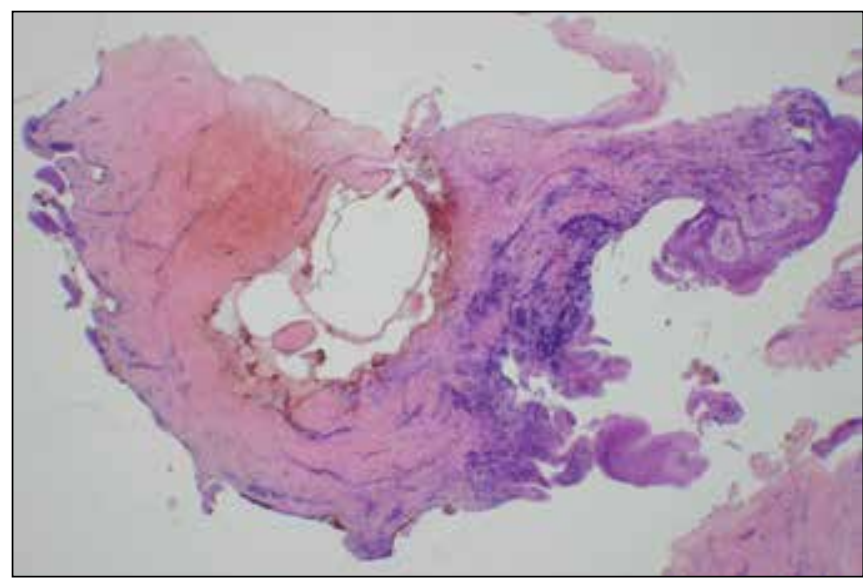

Fig. 4. Hematoma, epithelium defect and chronic proliferative inflammation in the mucosa covering the LTM. Photo of a histological specimen of a 26 year old patient. Hematoxylin-eosin staining, $\times 25$.

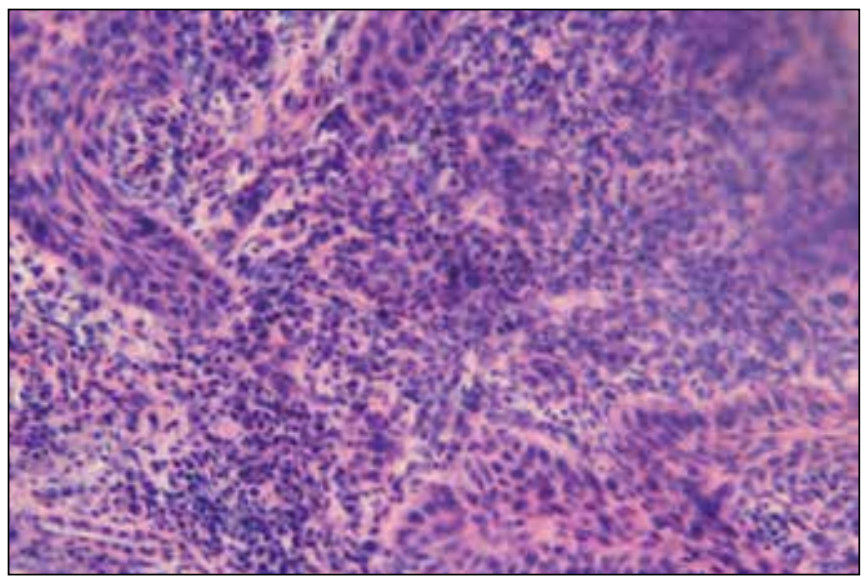

Fig. 6. Non-specific proliferative inflammation of high activity in the lamina propria mucosae, covering the LTM. Photo of a histological specimen of a 35 year old patient. Hematoxylin-eosin staining, $\times 160$.

various activity. The lamina propria mucosae, predominantly papillary layer, was infiltrated by mononuclears, macrophages, plasmacytes with admixture of foreign body multinucleated giant cells and abundance of degenerative cells (fig. 6). 


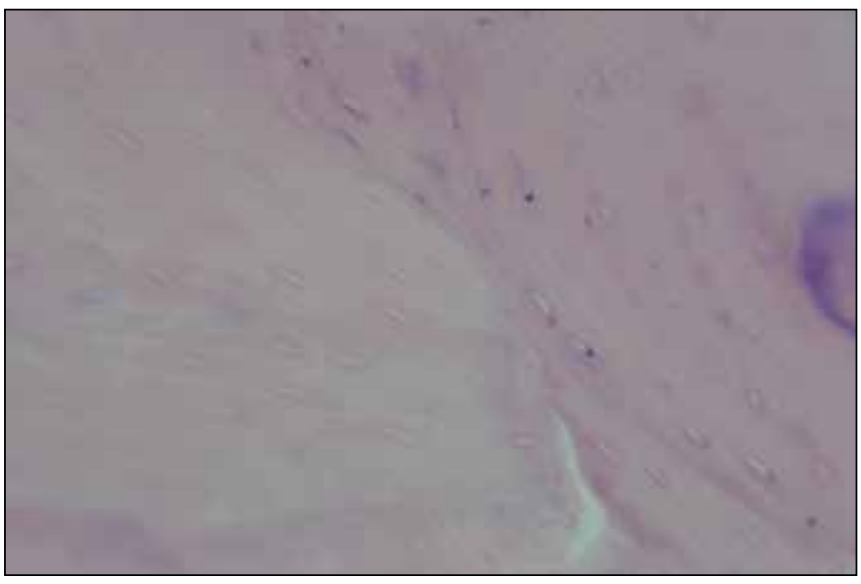

Fig. 7. Interstitial osteonecrosis in the bone tissue of the LTM alveolar margin. Photo of a histological specimen of a 33 year old patient. Hematoxylin-eosin staining, $\times 100$.

In case of bone tissue elements presence in biopsy specimen, the interstitial osteonecroses, determined by absence of osteocyte nuclei in groups of osseous lacunae, were most frequently registered (fig. 7). Occasionally, the areas of osteonecrosis constituted the major part of bone fragment. The signs of persistent remodeling, compacting periosteal regenerates were occasionally registered (fig. 8). The small foci of nonspecific inflammation of low activity, corresponding to histological pattern of nonspecific periostitis, were found in biopsy specimens in single cases [16].

The pathomorphological characteristics, their gradation and frequency distribution of cases are presented in table 2.

The correlation analysis findings of the relationship between clinical and morphological gradation parameters (table 3) evidence that only two of all studied pairs were characterized by absolute parameters of tetrachoric index higher than 0.2: «LTM position» - «damage of epithelium» and «pericoronitis activity as per clinical findings» - «activity of inflammation in the mucosa and submucosa». The meaning of the correlation relationship between the first pair of the parameters is that the vertical position of the LTM is more frequently associated with the lesser degree of mucosal epithelium damage (the parameter of tetrachoric index is certain); the meaning of the second pair is as follows - the high activity of pericoronitis as per clinical findings is more frequently associated with the high activity of inflammation in the mucosa and submucosa, determined during histological examination (the parameter of tetrachoric index is uncertain, considering the available number of follow-ups). However, the absolute values of tetrachoric index of both mentioned pairs correspond to weak relationship. The relationships in all other studied pairs «clinical signs - morphology» are even more weak and uncertain considering the available number of follow-ups.

The dependence between the «damage of the mucosal epithelium» and the "activity of inflammation in the mucosa» among the studied correlation pairs of the parameters «morphology - morphology» is strong positive, highly certain, which evidences the contingency of the damaged

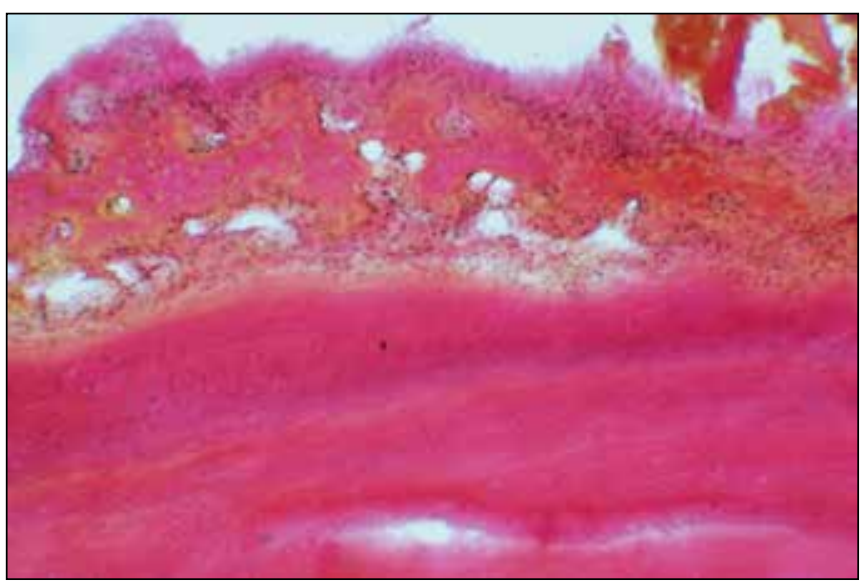

Fig. 8. Compacting periosteal regenerate on the surface of the bone tissue alveolar margin of the LTM. Photo of a histological specimen of a 27 year old patient. Staining with hematoxylin-picrofuchsin by van Gieson technique, $\times 50$.

epithelium and the high activity of inflammation in the majority of informative cases of biopsy examinations of the patients with the LTM complicated eruption.

\section{DISCUSSION}

As compared to the results of biopsy examinations of the «restricted» LTM presented in the references, our studies are less extensive and do not include the tissue elements of the tooth follicle, since, the teeth were not extracted in most cases and the economic resection of paradental tissue was performed. Such an approach did not always ensure the adequate representativity of biopsy specimen in relation to major pathological changes, which finally could influence the results of the correlation analysis in groups of «Clinical issues - morphology» and «Morphology - morphology» pairs.

The main cohorts of age groups of our patients, who underwent pericoronectomy, were subjects of both genders aged 20-30 which correspond to the cohorts of age groups of operated patients in the majority of specialized studies $[4,17]$. As opposed to some works, which determined the greater frequency of complications, related to the delayed eruption of the LTM in elder age groups $[4,5]$, our study did not confirm the strong correlation of age (groups of patients aged up to and included 25 and groups of patients aged over 25) and major pathological changes: damage of epithelium, discirculatory changes, activity of inflammation.

The range of pathological changes in paradental tissue, described in the related references, and their frequency are fairly well known, and their frequency is broadly variable [1, 2, 17-19]. Thus, the most frequent pathological processes in patients with «restricted» LTM were determined as follows: caries, paradental follicular cysts of a jaw; inflammatory processes in pericoronal tissue $[9,11,17,20$, 21]. The incidence of the follicular cysts in the proximity of the LTM varies from $2.1 \%$ [1] to 51\% [9]; the incidence of pericoronitis - from 4.8\% [9] to 66.5\% [1]. Some authors almost identify the retromolar pocket over $1 \mathrm{~mm}$ in width with epithelized walls and follicular cyst $[18,21]$. 
In our study, there were no specific changes found in paradental soft tissue which would allow to differentiate the follicular cyst and the pathological retromolar pocket with epithelization in those cases where no X-ray signs of cyst were present: hyperplasia of basal layers and areas of keratinization of squamous epithelium, fibrosis of the lamina propria, inflammatory infiltration of various types and density - can be observed in the retromolar pocket wall as well as in the mucosal fold, partially covering the LTM crown.

A range of researchers report on relatively high incidence of carious changes in the "restricted» LTM, which reaches $31 \%[13,18]$. However, only about $9 \%$ of all biopsy specimens of paradental tissue in our material were obtained of the patients with the determined LTM carious changes of various extent: moderate or deep caries.

In some earlier published works the authors attempted to define the dependence between the specific pathological changes in the LTM and paradental tissue and the position of the tooth in the lower jaw. Thus, it has been determined that the most marked difference in the nature of pathological changes in paradental tissue is observed with the distal oblique tooth position. The incidence of the damaged paradental tissue in the area of the «restricted» LTM in all positions in a dental arch was higher than with the absence of the complicated eruption [9].

Some researchers determined the certain correlation relationship between the parameter characterizing the LTM position and such complications as formation of cysts and abscesses in a jaw, jaw angle fracture [19]. Our findings on studying the correlation relationships between the LTM position in a dental arch and damaged epithelium of the mucosa showed only weak negative, but certain dependence, other pairs of parameters «LTM position in a jaw» and morphological parameters of paradental tissue damage showed values corresponding to very weak relationship (table 3).

The correlation analysis of the relationships of gradation morphological parameters of paradental soft tissue damage showed strong, certain, positive dependence between the damaged epithelium and the activity of inflammation in the soft tissue (mucosal fold, wall of retromolar periodontal pocket). However, the analysis of frequency distribution of cases of damaged epithelium and inflammation of high activity in groups with various age of clinical signs showed no significant differences.

The fact of the significant predominance of the number of weak dependencies in the results of the correlation analysis of the relationships of gradation clinical and morphological parameters we explain by multivariance and multidirectionality of influence on the certain parameters of morphological changes, the impact of which was difficult or impossible to consider when analyzing data.

The discirculatory and inflammatory processes, collectively known as "pericoronitis», play the utmost and probably the major role in the pathology of complications of the delayed LTM eruption, which is the subject of works of almost all researchers [1, 2, 15, 18, 22]. However, the assessment of the frequency, types and activity of nonspe- cific inflammatory process in paradental tissue is widely varied, even in the works where the histological method was applied. Some authors do not pay great attention to inflammatory processes among the most frequent pathological changes of the tissue in the region of the LTM [5, 20,21 ], others consider the inflammatory processes - acute and chronic - as the indications for therapeutic and surgical treatment of those complications, including the LTM extraction $[9,19]$.

However, the histological peculiarities of the inflammatory processes in paradental tissue are not presented in the mentioned works, due to which it is impossible to make a fair judgment of inflammation activity, its correlation with clinical parameters of complications of the LTM eruption in many cases. In our material of histological examinations of biopsy specimens of the paradental tissue, the inflammatory processes were found in the majority of biopsy specimens, moreover, the nonspecific inflammatory process of high activity was histologically confirmed in half of the cases: proliferative infiltrative, of high activity, or exudative, more often fibrinous or purulent. In separate follow-ups, where the biopsy material included fragments of bone tissue of the alveolar wall, the small areas of nonspecific proliferative inflammation of low activity were observed, this can be considered as a manifestation of small focal fibrotic osteomyelitis of low activity.

We did not encounter the descriptions and pathogenetic evaluation of local discirculatory changes in soft and bone tissue in the works related to the study of histological changes of paradental tissue with complications of the LTM eruption. The careful consideration of the characteristic signs of the pathology: the areas of ischemic fibronecrosis and osteonecrosis, microhematomas in the lamina propria mucosae and submucosa, showed that the similar changes are found approximately in the half of all biopsy specimens, however, no strong correlation of the pathology with any clinical or morphological parameters was established in our study. The relatively high frequency of incidence of the discirculatory changes in paradental tissue is most probably caused by frequent traumas of the mucosa, covering the LTM crown.

The main point of the issue of labored LTM eruption and its complications is which extent of pericoronitis in case of absence of the damage to the hard tissue of a tooth justifies the so called "preventive» LTM extraction. Many authors consider that the extraction of the LTM is reasonable in case of the developed pericoronitis, particularly in combination with deep and complicated caries, apical periodontitis, osteomyelitis, paradental cysts or abscesses $[10,17,18,22]$. However, a range of researchers, including those who conducted histological examination of the resected tissue, insist on the "preventive» extraction of the intact LTM relying only on the probability of the complications development, which indeed are more frequently observed in this region rather than in other places of a dental arch [6-8].

The known published works with conducted metanalysis of the controlled comparative studies evidence of the 
absence of current reliable data confirming the positive outcome and providing convincing arguments of the necessity of preventive extraction of the intact LTM [23, 24].

Our views on the issue are based on the results of clinical and morphological examinations presented in the paper. In our opinion, the probability of the possible pathological changes in the hard tissue of a tooth in the long-term is not a fundamental argument in favor of its extraction, but represents the complex of indications for the relevant therapeutic and surgical treatment.

\section{CONCLUSIONS}

1. The local pathological processes, which chronologically precede the destructive changes in the hard tissue of a tooth (caries), are developed in patients of both genders with complicated LTM eruption in soft tissue of parodontium and the adjacent bone tissue of the alveolar wall in the majority of cases.

2. As per biopsy examinations, the frequency of the main pathological processes in paradental tissue in case of complicated LTM eruption varies from 25 to $60 \%$ of the number of biopsy specimens and occurs in various combinations in patients with different values of clinical parameters.

3. The correlation relationships between the patients' clinical data and the morphological parameters of damage to paradental tissue are weak, multidirectional and uncertain in the majority of combinations (considering the available number of biopsy specimens studied).

4. The close certain positive dependence between the damage of the squamous epithelium and the inflammation activity in the lamina propria mucosae, covering the tooth: in the vast majority of cases, the presence of damaged epithelium (within the biopsy specimen) is associated with the inflammation of high activity, was established as based on correlation relationships between the morphological parameters of damage to paradental tissue.

\section{REFERENCES}

1. Magid EA, Sheinberg VM, Zhitnitsky GD. Zatrudnennoe prorezyvanie nizhnih zubov mudrosti i svjazannye s nim oslozhnenija. Difficulty eruption of lower wisdom teeth and associated complications. Volgograd, 1970. 122 p. (Ru).

2. Adelsperger J, Campbell JH, Coates DB, Summerlin D-J, Tomich ChE. Early soft tissue pathosis associated with impacted third molars without pericoronal radiolucency. Oral Surgery, Oral Medicine, Oral Pathology, Oral Radiology, Endodontology. 2000;89(4):402-406.

3. Volovar 0, Topchii D, Logvynenko I, Dobryi-Vechir T, Oblap M. Internal changes of TMJ at young people with different somatotypes. International Journal of Pharmaceutical Research. 2020;1:1465-1469.

4. Chiapasco M, Crescentini M, Romanoni G. Germectomy or delayed removal of mandibular impacted third molars: the relationship between age and incidence of complications. Journal of Oral and Maxillofacial Surgery. 1995;53(4):418-422.

5. Curran AE, Damm DD, Drummond JF. Pathologically significant pericoronal lesions in adults: histopathologic evaluation. Journal of Oral and Maxillofacial Surgery. 2002;60(6):613-617.
6. Gröndahl H-G, Lekholm U. Influence of mandibular third molars on related supporting tissues. International Journal of Oral and Maxillofacial Surgery. 1973;2(4):137-142.

7. Hinds EC, Frey KF. Hazards of retained third molars in older persons: report of 15 cases. The Journal of the American Dental Association. 1980;101(2):246-250.

8. Marciani RD. Third molar removal: an overview of indications, smaging, evaluations, and assessment of risk. Oral and Maxillofacial Surgery Clinics of North America. 2007;19(1):1-13.

9. Rakprasitkul S. Pathologic changes in the pericoronal tissues of unerupted third molars. Quintessence International. 2001;32(8):633-638.

10. Adeyemo WL. Do pathologies associated with impacted lower third molars justify prophylactic removal? A critical review of the literature. Oral Surgery, Oral Medicine, Oral Pathology, Oral Radiology, Endodontology. 2006;102(4):448-452.

11. Eliasson S., Heimdahl A., Nordenram A. Pathological changes related to long-term impaction of third molars/a radiographic study. International Journal of Oral and Maxillofacial Surgery. 1989;18(4):210-212.

12. Hicks EP. Third molar management: a case against routine removal in adolescent and yong adult orthodontic patients. Journal of Oral and Maxillofacial Surgery. 1999;57(7):831-836.

13. Van der Linden W, Cleaton-Jones P, Lownie M. Diseases and lesions associated with third molars: review of 1001 cases. Oral Surgery, Oral Medicine, Oral Pathology, Oral Radiology, Endodontology. 1995;79(2):142-145.

14. Almendros-Marqués N, Alajejos-Algarra E, Quinteros-Borgarello M, Berini-Aytés L, Gay-Escoda C. Factors influencing the prophylactic removal of asymptomatic impacted lower third molars. International Journal of Oral and Maxillofacial Surgery. 2008;37(1):29-35.

15. Baykul T, Salgam A, Aydin U, Basak K. Incidence of cystic changes in radiographically normal impacted lower third molar follicles. Oral Surgery, Oral Medicine, Oral Pathology, Oral Radiology, Endodontology. 2007;99(5):542-545.

16. Ruzin GP,TkachenkoOV,MiroshnichenkoMS,PlitenON.Pathomorphological features of chronic toxic osteomyelitis in drug addicts taking amphetamine of a street drugs brand. Likars'ka sprava. 2013;4:87-93.

17. Stanley HR, Alattar M, Collett WK, Stringfellow HRJr, Spiegel EH. Pathological sequelae of "neglected" impacted third molars. Journal of Oral Pathology and Medicine.1988;12(3):113-117.

18. Al-Khateeb T, Bataineh A. Pathology associated with impacted mandibular third molars in a group of iordanians. Journal of Oral and Maxillofacial Surgery. 2007;64(11):1598-1602.

19. Werkmeister R, Fillies T, Joos U, Smolka K. Relationship between lower wisdom tooth position and cyst development, deep abscess formation and mandibular angle fracture. Journal of Cranio-Maxillofacial Surgery. 2005;33(3):164-168.

20. Glosser JW, Campbell JH. Pathologic change in soft tissues associated with radiographically"normal" third molar impactions. British Journal of Oral and Maxillofacial Surgery. 1999;37(4):259-260.

21. Manganaro AM. The likelihood of finding occult histopathology in routine third molar extractions. General Dentistry. 1998;46(2):200-202.

22. BadheriSC, Khan H.A. Extraction versus nonextraction management of third molars. Oral and Maxillofacial Surgery Clinics of North America. 2007;19(1):15-21.

23. Mettes TG, Nienhuijs ME, van den Sanden WJ, Verdonschot EH, Plasschaert AJ. Interventions for treating asymptomatic impacted wisdom teeth in adolescents and adults. Cochrane Database of Systemic Reviews. 2005;18(2):CD003879. 
24. Song F, Landes DP, Glenny AM, Sheldon TA. Prophylactic removal of impacted third molars: an assessment of published reviews. British Dental Journal. 1997;182(9):339-346.

\section{ORCID and contributionship:}

Vladislav A. Malanchuk - 0000-0001-8111-0436

Oksana S. Volovar - 0000-0002-6724-0266 $6^{B, F}$

Mykola V. Oblap - 0000-0002-5959-2624 $4^{B, D}$

Igor S. Brodetskyi - 0000-0002-9434-4079

Tatyana V. Dobryi-Vechir - 0000-0002-7390-3505,

Valerii V. Hryhorovskyi - 0000-0002-6375-1595

Liudmyla O. Brodetska - 0000-0002-0570-3085

Olena O. Dyadyk - 0000-0002-9912-4286

Mykhailo S. Myroshnychenko - 0000-0002-6920-8374 ${ }^{E, F}$

\section{Conflict of interest:}

The Authors declare no conflict of interest

\section{CORRESPONDING AUTHOR}

Mykhailo S. Myroshnychenko

Kharkiv National Medical University,

Pathological Anatomy Department.

Str. Svetlaya 27A, apt. 70, 61129, Kharkiv, Ukraine

tel: +380501699763, +380961033038

e-mail:msmyroshnychenko@ukr.net

Received: 15.11 .2020

Accepted: 23.02.2021

A - Work concept and design, B - Data collection and analysis, C - Responsibility for statistical analysis, D-Writing the article, $\mathbf{E}$-Critical review, $\mathbf{F}$ - Final approval of the article 